\title{
A magzatok és embriók kereskedelmi és ipari célú felhasználásának morális és jogi kérdései
}

\author{
embrió - magzat - szabadalom - abortusz - oviedói egyezmény
}

Napjainkra a kereskedelmi forgalomban kapható egyes fogyasztási cikkek magzatok sejtjeinek, szöveteinek felhasználásával készülnek. Ilyen termékek különösen egyes vakcinák, kozmetikai cikkek vagy akár élelmiszerek. ${ }^{1} \mathrm{~A}$ védőoltások körében számos vakcina², így például a hazánkban is kötelező védőoltás, a mumpszkanyaró-rubeola (MMR) ellen kifejlesztett, Magyarországon engedélyezett és forgalomban lévő oltóanyag (MMR-VAXPRO) művi abortuszból származó sejtvonalak felhasználásával készült. A kozmetikai termékek körében a Neocutis svájci kozmetikai cég PSP ${ }^{\circledR}$ (Processed Skin Cell Proteins) fejlesztésével kapcsolatban láttak napvilágot olyan hírek, miszerint a $\mathrm{PSP}^{\circledR}$-összetevő abortumból származó sejtvonalakkal készült. ${ }^{3}$ Végül, az élelmiszergyártás területén az egyesült államokbeli Senomyx vállalat került reflektorfénybe a HEK 293 (Human Embryonic Kidney cells) sejtvonalak miatt, mellyel élelmiszergyártó cégek termékeihez fejlesztettek ízfokozókat. ${ }^{4}$

A magzatok kereskedelmi célú felhasználásával kapcsolatban hazánkban is merültek fel aggályok; erről tanúskodik az alapvető jogok biztosa és a jövő nemzedékek érdekeinek védelmét ellátó biztoshelyettes AJB-3119/2014 számú ügyben kiadott közös jelentése. Az ügyben a panaszosok azért fordultak a jövő nemzedékek ér-

* Dr. Láncos Petra Lea egyetemi docens, Pázmány Péter Katolikus Egyetem Jog- és Államtudományi Kar Európajogi Tanszék, lancos.petra.lea@jak.ppke.hu. Köszönettel tartozom Navratyil Zoltánnak, Mogyoróssy Dorottyának, Pump Juditnak, Perecsenyi Melindának, Sulyok Katalinnak, Bosányi Eszternek és a lektoroknak az írással kapcsolatos útmutatásokért, segítségért.

1 http://www.lifesitenews.com/news/its-not-just-pepsi-drug-food-cosmetic-companies-use-aborted-babycells-says/ (2015. 10. 02.); http://www.immunize.org/concerns/vaticandocument.htm (2015. 10. 02.); MARIETTA, Cynthia S.: Ingredient in Anti-Aging Cosmetic Re-Ignites Abortion Debate and Raises Questions About Cosmetic Labeling. http://www.law.uh.edu/healthlaw/perspectives/2010/(CM)\%20Cosmetic.pdf (2015. 10. 02.).

2 Rubeola: Meruvax II, Rudivax, Ervevax (RA 27/3); rubeola-kanyaró kombinált vakcina: M-R-VAX, RudiRouvax; rubeola-mumpsz kombinált vakcina: Biavax II, MMR (kanyaró-mumpsz-rubeola) kombinált vakcina: M-M-R II, Trimovax, Priorix; hepatitis A: VAQTA, HAVRIX; bárányhimlő: Varivax; gyermekbénulás: Poliovax; veszettség: Imovax; himlő: AC AM 1000. http://www.immunize.org/concerns/vaticandocument.htm (2015. 10. 02.).

3 Lásd például: MarietTA, Cynthia S.: Ingredient in Anti-Aging Cosmetic Re-Ignites Abortion Debate and Raises Questions About Cosmetic Labeling. http://www.law.uh.edu/Healthlaw/perspectives/2010/(CM)\%20 Cosmetic.pdf (2015. 10. 02.); http://www.washingtontimes.com/news/2009/nov/3/aborted-fetus-cells-usedin-anti-aging-products/?page=all (2015. 10. 02.); a cég saját oldalán: http://www.neocutis.com/technology/ detail/1. (2015. 10. 02.).

4 Lásd például: http://www.washingtontimes.com/news/2012/apr/30/pro-lifers-drop-pepsi-boycott/ (2015. 10. 02.). 
dekeinek védelmét ellátó biztoshelyetteshez, mert a népegészségügyi intézet eljárást indított ellenük gyermekeik kötelező oltásának elmaradása miatt. A panaszosok ugyan a gyermekeik tekintetében fennálló oltási kötelezettségüknek mindenképpen eleget kívántak tenni, ám a Magyarországon engedélyezett és forgalomban lévő, múvi abortuszból származó sejtvonalak felhasználásával készült vakcina helyett vallási meggyőződésükre tekintettel ${ }^{5}$ egy alternatív oltóanyag importjának engedélyezését kérték az illetékes hatóságtól, ám a GYEMSZI-OGYI (Gyógyszerészeti és Egészségügyi Minőség- és Szervezetfejlesztési Intézet - Országos Gyógyszerészeti Intézet) az engedély iránti kérelmet első körben elutasította. Habár a lelkiismereti és vallásszabadság tekintetében az egyes magzati sejtvonalak felhasználásával készült oltóanyagok is problémát jelenthetnek, ${ }^{6}$ az alábbiakban különösen az élelmiszerek és kozmetikumok eseteire térek ki, hiszen ezek nem tartoznak az olyan diagnosztikai, terápiás és gyógyászati felhasználások körébe, melyeket kivételesen még a Szentszék is elfogad. ${ }^{7}$

A magzatok, esetleg embriók kereskedelmi célú hasznosítása súlyos morális aggályokat és jogi kérdéseket vet fel. Így felmerül a) a magzat „személyi integritása” és az elpusztult magzat kezelésével kapcsolatos kérdések; $b$ ) a tájékozott beleegyezés és az anya rendelkezési jogának sérelme a testéböl távozott magzat, illetve az in vitro megtermékenyített embrió további sorsa felett; c) a fogyasztók lelkiismereti szabadságának és fogyasztóvédelmi jogainak sérelme a magzatok vagy embriók felhasználásával vagy kísérleti jellegủ felhasználásával készült termékekkel kapcsolatos megfelelő információk hiánya, illetve a hatóságok által esetlegesen elkövetett visszásságok miatt. A következőkben a magzatok vagy embriók kereskedelmi célú felhasználása alatt az emberi abortumok, illetve a humán reprodukciós eljárásban létrehozott embriók egyes termékek gyártását, fejlesztését vagy tesztelését szolgáló, haszonszerzési célú felhasználását értem. ${ }^{8} \mathrm{~A}$ jelen írás célja, hogy ezzel összefüggésben számba vegye a magzatok és embriók kezelésével kapcsolatos hazai, európai jogi és nemzetközi jogforrásokat, és rávilágítson azokra a morális aggályokra és jogi kérdésekre, melyek a tudomány fejlődésével és a kereskedelem liberalizációjával a továbbiakban rendezést igényelnek.

5 A Szentszék álláspontja alapján az orvosok, családapák kötelessége, hogy (amennyiben azok rendelkezésre állnak) alternatív vakcinákat vegyenek igénybe, ezzel is nyomást gyakorolva a hatóságokra és az egészségügyi rendszerekre abból a célból, hogy a morálisan nem megkérdőjelezhető vakcinák széles körben elérhetővé váljanak. PONTIFICAL ACADEMY FOR LIFE: Moral Reflections on Vaccines Prepared from Cells Derived from Aborted Human Fetuses. National Catholic Bioethics Quarterly, 2006 Autumn, 6 (3), 541-50.

6 BALÁK, René: Mandatory Vaccination and Conscientious Objection. Forum Teologiczne, 2014, 69-70.

7 Pontifical Academy for Life: Moral Reflections on Vaccines Prepared from Cells Derived from Aborted Human Fetuses. National Catholic Bioethics Quarterly, 2006 Autumn, 6 (3), 541-50.

8 Lásd SÁNDOR Judit-VARJu Márton: Az embrionális őssejteken végzett kutatások és az ezeken alapuló találmányok etikai aspektusai. In: Rózsa Erzsébet-Kőműves Sándor-Kovács József (szerk.): A személy bioetikai kontextusa. Debreceni Egyetemi Kiadó, Debrecen, 2013, 128. 


\section{A magzat „személyi integritása” és az embrió kezelésével kapcsolatos kérdések}

Az Unió Alapjogi Chartájának 3. cikk (2) bekezdés c) pontja szerint: „[(2) Az orvostudomány és a biológia területén különösen a következőket kell tiszteletben tartani:] az emberi test és részei ekként történő, haszonszerzési célú felhasználásának tilalma."

Az Alaptörvény III. cikk (3) bekezdése a következőképpen rendelkezik: „[Tilos] az emberi test és testrészek haszonszerzési célú felhasználása."

Az idézett jogalapok hatályával kapcsolatban érdemes kiemelni, hogy míg az Alapjogi Charta 3. cikk (2) bekezdés c) pontja a Charta 51. cikk (1) bekezdése alapján csupán az Unió jogának végrehajtása során alkalmazandó, ${ }^{9}$ addig az Alaptörvény hasonló rendelkezésével immár az ún. „tisztán tagállami tényállások” körében is tilos az emberi test és részei haszonszerzési célú felhasználása. Szembetűnő a két idézett rendelkezés szinte szó szerinti azonossága. Azonban szemben az Alapjogi Chartával, az Alaptörvény nem szükíti le „az orvostudomány és biológia területére” az emberi test és részei haszonszerzési célú felhasználásának tilalmát. Kérdéses, hogy mit takar pontosan az „orvostudomány és a biológia területén” fordulat: vajon a tilalom az orvostudomány és biológia körére korlátozódik, vagy teljes tilalom alá esik az emberi test és részei haszonszerzési célú felhasználása az uniós jog alkalmazásának körében? Mivel az Alaptörvény e ponton kifejezetten nem utal a Chartára, az idézett két rendelkezés tárgyi hatálya potenciálisan eltérhet. ${ }^{10}$

Emellett kérdésként merülhet fel, hogy vajon az Alapjogi Charta és az Alaptörvény „emberi test és részei” fordulatának hatálya alá tartoznak-e a magzatok és emberi embriók vagy sem. A Charta vonatkozó rendelkezésével kapcsolatban az Alapvető Jogok Független Szakértőinek Uniós Hálózata által kiadott Kommentár ${ }^{11}$ szerint: „Az embrió genetikai mérnökösködés és más jogszerütlen kutatással szembeni védelme [...] jól mutatja, hogy a személyes integritáshoz való jog kiterjed a meg nem született gyermekre és még a jövő nemzedékekre is." Mindezek alapján arra következtethetünk, hogy - legalábbis az uniós jog alapján - az embrió az „emberi test részének” tekinthető, továbbá a személyes integritáshoz való jog az embriót, illetve a magzatot is megilleti.

9 51. cikk (Alkalmazási kör) (1) bekezdés: „E Charta rendelkezéseinek címzettjei - a szubszidiaritás elvének megfelelő figyelembevétele mellett - az Unió intézményei, szervei és hivatalai, valamint a tagállamok annyiban, amennyiben az Unió jogát hajtják végre."

10 Ugyanis az Európai Bíróság állandó joggyakorlata szerint az olyan nemzeti rendelkezések, melyek akár szó szerint vesznek át az uniós jogban szabályozott rendelkezéseket, abban az esetben bírnak az uniós joggal azonos tartalommal - és az Európai Bíróság csak abban az esetben értelmezi az azonos szövegü nemzeti jogszabályt tisztán tagállami helyzetekben -, ha a nemzeti jogszabály utal arra, hogy egy adott uniós rendelkezés tagállami átültetéséröl van szó. C-297/88. és C-197/89. sz., Dzodzi-ügyben 1990. október 18-án hozott ítélet 36. és 41. pont (ECLI:EU:C:1990:360). C-346/93. sz., Kleinwort Benson Ltd kontra City of Glasgow District Council ügyben 1995. március 28-án hozott ítélet, 16-17. pont (ECLI:EU:C:1995:85).

11 EU Network of Independent Experts on Fundamental Rights: Commentary on the Charter of Fundamental Rights of the European Union. 2006, 39-40. http://ec.europa.eu/justice/fundamental-rights/files/networkcommentaryfinal_en.pdf (2015.10. 02.). 
Az embrió és magzat uniós jog alapján fennálló személyes integritásához fủződő jog kiindulópontot jelenthet az elpusztult magzat kezelésének megítélésére, függetlenül attól, hogy a magzatnak élethez való joga nincs, illetve nem terjed ki rá az állam élő magzatokkal kapcsolatos objektív intézményvédelmi kötelezettsége. Hasonlóképpen az állampolgári jogok országgyülési biztosa az elhalt magzatok kezeléséröl szóló, AJB 4291/2010. sz. ügyben kiemelte, hogy az Alkotmány (1949. évi XX. tv.) 54. § (1) bekezdése alapján „minden embernek veleszületett joga van az élethez és az emberi méltósághoz, amelyektöl senkit nem lehet önkényesen megfosztani. A kegyeleti jog az emberi méltósághoz való joghoz kapcsolódik, ugyan az elhunyt jogalanyisága megszünik, de teljesen nem enyészik el: maga a halál ténye ugyanis nem járhat azzal, hogy az elhunyt emlékét, a holttestet vagy a síremléket ne illetné meg semmiféle jogi védelem." Az állampolgári jogok országgyülési biztosának kategorikus, kivételeket meg nem engedő állítása arra enged következtetni, hogy az emberi méltóságból fakadó kegyeleti jog a magzatot is megilleti - „anyagával” kellő tisztelettel kell bánni. ${ }^{12,13}$

Ami az emberi test és részei haszonszerzési célú felhasználását illeti, a Chartához készült Kommentár szerzői szerint „bár a haszonszerzési célú felhasználás tilalma igen abszolút módon került megfogalmazásra, ez alól bizonyos kivételek tehetök [...] A Charta 3. cikk (2) bekezdése nem tiltja az emberi test részeinek eladását vagy azzal kapcsolatos kereskedelmet, csupán azt, hogy azok haszonszerzés forrásául szolgáljanak." Míg a Kommentár alapján az emberi test és részeinek bizonyos tudományos célokból való felhasználása mentesülhet a tilalom alól, a magzatok és emberi embriók kereskedelmi forgalomban elérhető termékek vagy szolgáltatások kifejlesztése vagy javítása érdekében történő hasznosítása olyan felhasználást jelent, melyben azok „haszonszerzés forrásául szolgálnak”.

12 Ehhez képest a magyar jog kifejezetten csupán az elpusztult magzatok (a terhesség 12. hetétől számított élettani szakasz) tekintetében biztosít bizonyos kegyeleti jellegü jogokat. A temetőkről és a temetkezésröl szóló 1999. évi XLIII. törvényben az elhunyt személyekkel azonos szabályokat rendel alkalmazni az elpusztult magzatokra [2. § (4) bekezdés: „A halva született és elvetélt magzatok [...] eltemetésével öszszefüggésben - ha jogszabály másként nem rendelkezik - e törvényben foglaltakat kell alkalmazni]." A jogszabály 24. §-ának (4) bekezdése szerint „korai vagy középidős magzati halálozás esetén az elhalt magzat halottvizsgálati bizonyítvány nélkül, a szülő írásbeli nyilatkozata alapján temethető vagy hamvasztható el. A nyilatkozat alapján a maradványokat ki kell adni, a szülő azok eltemettetésére köteles." Az elpusztult magzatokkal (művi és természetes vetélés, perinatális halál) kapcsolatos szabályozás szerint egyébként az elpusztult magzat „anyagát” ún. gratisládákban helyezik el és temetik el.

13 Teljességgel érthetetlen ugyanakkor, hogy a 2011. évi CCl. törvény az egyes törvények Alaptörvénnyel összefüggő módosításáról 177. §-ában miért helyezte hatályon kívül a temetőkről és a temetkezésről szóló 1999. évi XLIII. törvény 14. §-át, mely a halva született magzatok sírhelyével kapcsolatos szabályokat tartalmazta. A hatályon kívül helyezett paragrafus szerint: „(2) A halva született magzat sírhelyét jelzőtáblával kell megjelölni, amelyen a temetés napját és a temetési hely sorszámát kell feltüntetni. (3) Ha a halva született magzat eltemetéséröl - kérésére - közeli hozzátartozója gondoskodott, a sírhelyen kereszt vagy fejfa is elhelyezhető, és azon utónevet is fel lehet tüntetni." 


\section{Az emberi embrión végzett kutatások az oviedói egyezmény alapján}

A hazánk által is ratifikált oviedói egyezmény 18. cikke az alábbiak szerint rendelkezik: ${ }^{14}$ „Embriókon végzett in vitro kutatás

a) Amennyiben az embriókon végzett in vitro kutatást a törvény megengedi, a törvénynek megfelelö védelmet kell biztosítania az embrió számára.

b) Emberi embrió létrehozása kutatás céljából tilos."

Az oviedói egyezmény nem tiltja az emberi embriókon végzett kutatást, azonban arra négy feltétel együttes megvalósulását írja elő: (i) az emberi embriókon végzett kutatásra a törvény lehetőséget biztosít; (ii) az emberi embriót nem kutatási célra hozzák létre; (iii) az emberi embrión végzett kutatás in vitro feltételek között történik; (iv) a törvény a kutatás feltételeivel kapcsolatban megfelelő védelmet biztosít az embrió számára.

Az egyezmény garanciális szabályként tartalmazza, hogy emberi embriót kutatási célból létrehozni tilos. Amennyiben azonban az embrió - más célból - létrejött, az egyezmény a törvényi felhatalmazás feltételével nem tiltja az ezeken végzett kutatásokat.

$E$ helyütt érdemes megemlíteni, hogy bár a humán reprodukciós eljárások során létrejött embriók létrehozásának elsődleges célja nem a kutatásokban történő felhasználásuk, az a tény, hogy az emberi embriókat (orvosi szempontokat figyelembe véve, a donor megkímélése céljából) in vitro nagy mennyiségben hozzák létre, azzal a következménnyel jár, hogy nagy mennyiségben rendelkezésre áll humán reprodukciós célból fel nem használt emberi embrió. Mindezek alapján, céltól függetlenül a humán reprodukciós eljárások végeredménye az lesz, hogy a be nem ültetett embriókat kutatási célra használják fel vagy megsemmisítik, azaz az eljárás következménye éppen a kutatási célú felhasználások kiszolgálása. Az egyezmény fenti, garanciális szabálya tehát egy morális megfontolás kifejezésre juttatása, mely nem zárja ki a „legitim” célokból létrehozott embriókon végzett kutatást. ${ }^{15}$ Pedig, miként Navratyil fogalmaz: „a reprodukciós célra létrehozott, de megmaradt embrió között és a kifejezetten kutatási célra létrehozott embriók között elvileg nincsen különbség morális státusukat illetően. A megmaradt embriók közül is többen elpusztulnak, mert nem használják fel őket. Számít-e vajon, hogy eredetileg milyen szándékkal fogant?"16

Navratyil arra is rámutat, hogy „az egyezmény több általa használt alapvető fogalmat [...] nem definiál, s nem határozza meg a »kutatási cél« (research purposes) mibenlétét sem". ${ }^{17}$ Az emberi jogokról és a biomedicináról szóló, irányadó nemzetközi jogforrás tehát kifejezetten nyitva hagyja az emberi embriókon végezhető kutatások jellegét és célját. Mindezek alapján az egyezmény nem zárja ki, hogy a legitim cél-

14 Az Európa Tanácsnak az emberi lény emberi jogainak és méltóságának a biológia és az orvostudomány alkalmazására tekintettel történő védelméröl szóló, Oviedóban, 1997. április 4-én kelt Egyezménye. Magyarországon kihirdette a 2002. évi VI. törvény.

15 Lásd még NAVRATYIL Zoltán: A varázsló eltöri pálcáját? A jogi szabályozás vonulata az asszisztált humán reprodukciótól a reproduktív klónozásig. Gondolat, Budapest, 2012, 164.

16 NaVRATYIL: i .m., 238.

17 NaVRATYIL: i. m., 114-116. 
ból létrehozott embrión olyan kutatásokat folytassanak, melyek bizonyos termékek, szolgáltatások kifejlesztését szolgálják.

Végül az egyezmény az embriókon végzett in vitro kutatásokra felhatalmazó nemzeti törvénnyel kapcsolatban annyit követel meg, hogy az ",megfelelő védelmet" biztosítson az embrió számára. Arra vonatkozóan azonban, hogy ezt a védelmet milyen formában nyújtsa a törvény (például: kutatás céljának, módjának, időtartamának korlátozásai), az egyezmény már nem tartalmaz semmiféle iránymutatást.

\section{Orvostudományi kutatások, felhasználások és találmányok}

\subsection{Uniós jogi fejlemények}

Az emberi embriók orvostudományi kutatási és kereskedelmi célú felhasználásának megítélése tekintetében érdekes adalékokkal szolgált az Oliver Brüstle kontra Greenpeace eV ügy. ${ }^{18}$

Az ügyben az embrionális őssejtekből előállított idegi elősejtek és azok gyógyászati célú felhasználásának szabadalmaztathatósága merült fel kérdésként a biotechnológiai találmányok jogi oltalmáról szóló, az Európai Parlament és a Tanács 98/44/EK irányelve tükrében. A Bíróság szerint az embrió fogalmát - mivel ugyan az irányelv nem ad meghatározást a fogalomra, ám a nemzeti jogokra sem tesz utalást - az irányelv alkalmazása tekintetében az uniós jog önálló fogalmának kell tekinteni. ${ }^{19}$ Habár e fogalom tartalma „számos tagállamban igen érzékeny társadalmi kérdés, amelyet a tagállamok értékrendjének és hagyományainak sokfélesége jellemez", a fogalom kiindulópontja az emberi méltóság tiszteletben tartása, így azt szélesen kell értelmezni. „Ebben az értelemben minden emberi petesejtet már a megtermékenyitésének szakaszától kezdve »emberi embriónak" kell tekinteni az irányelv 6. cikke (2) bekezdésének c) pontja értelmében és annak alkalmazása céljából, amennyiben e megtermékenyités az emberi egyeddé fejlódés folyamatának beindítója. Ugyanezt a minősitést kell elfogadni azon megtermékenyitetlen emberi petesejtekre is, amelyekbe egy érett emberi sejtből származó sejtmagot ültettek át, valamint azon megtermékenyitetlen emberi petesejtekre, amelyeket szüznemzés útján osztódásra és továbbfejlődésre ösztönöztek. Habár ezek az organizmusok tulajdonképpeni értelemben nem estek át megtermékenyítésen, ezek - amint a Bírósághoz benyújtott írásbeli észrevételekből kitünik - a petesejt megtermékenyitésével létrejött embrióhoz hasonlóan a kinyerésükre alkalmazott eljárás révén képesek beinditani az emberi egyeddé fejlödés folyamatát."20

Ehhez képest „az emberi embrióból a blastocysta-szakaszban nyert őssejteket illetően a nemzeti bíróságnak kell a tudomány állására tekintettel meghatároznia,

18 C-34/10. sz., Oliver Brüstle kontra Greenpeace eV ügyben 2011. október 18-án hozott ítélet (ECLI:EU:C:2011:669).

19 C-34/10. sz., Brüstle-ügyben hozott ítélet, 26. pont.

20 C-34/10. sz., Brüstle-ügyben hozott ítélet, 35-36. pont. 
hogy ezek beindíthatják-e az emberi egyeddé fejlődés folyamatát, és következésképpen az irányelv 6. cikke (2) bekezdésének c) pontja értelmében és annak alkalmazása céljából az »emberi embrió« fogalma alá tartoznak-e." ${ }^{21}$ Az irányelv 6. cikke szerint közrendbe vagy közerkölcsbe ütközik és nem részesülhet szabadalmi oltalomban az emberi embrió ipari vagy kereskedelmi célú alkalmazása, ${ }^{22}$ kizárólag az emberi embrión alkalmazott gyógyászati vagy diagnosztikai célú és annak javát szolgáló alkalmazás lehet szabadalom tárgya. Végül, egy találmány nem szabadalmaztatható, ha az „megköveteli az emberi embriók előzetes elpusztítását vagy alapanyagként történő alkalmazását, bármelyik szakaszban is kerül sor ezekre”. ${ }^{23}$

Az Európai Parlament és a Tanács 2004/23/EK irányelve az emberi szövetek és sejtek adományozására, gyüjtésére, vizsgálatára, feldolgozására, megőrzésére, tárolására és elosztására vonatkozó minőségi és biztonsági előirások megállapításáról a gyógyászati célú beavatkozások tekintetében szabályozza az emberi szövetek és sejtek kezelését és (7) preambulumbekezdésében a magzati szöveteket és sejteket, embrionális őssejteket kifejezetten a hatálya alá vonja. Egyben (12) preambulumbekezdésében kimondja, hogy „az irányelv nem sértheti a tagállamok által az emberi sejtek meghatározott típusainak, ezen belül a csírasejtek és az embrionális őssejtek felhasználására vagy fel nem használására vonatkozó határozatait”. Az irányelv (22) preambulumbekezdése alapján „az irányelv tiszteletben tartja az alapvető jogokat és az Európai Unió alapjogi chartájában tükröződő elveket". Hasonlóképpen a Tanács 2006/974/EK határozata az Európai Közösség kutatási, technológiafejlesztési és demonstrációs tevékenységekre vonatkozó hetedik keretprogramjának (2007-2013) végrehajtására irányuló „Kapacitások” egyedi programról 4. cikkének (2) bekezdésében kifejezetten kizárja a finanszírozásból az emberi embriók kizárólag kutatási célból történő létrehozására és őssejtekhez jutásra irányuló kutatási tevékenységeket és - tekintettel a tagállamok e tekintetben képviselt sokszínüségére, kimondja, hogy „az embrionális emberi őssejteken végzett kutatások [...] az érintett tagállam(ok) jogi keretének függvényében finanszírozhatók".

Ezzel kapcsolatban érdemes megemlíteni, hogy a legelső európai polgári kezdeményezés, az „Egy közülünk” keretében a tizenegy tagállamból származó aláírók azt indítványozták, hogy az Unió hagyjon fel minden, emberi embriók lehetséges elpusztításával járó tevékenység finanszírozásával, kifejezetten beleértve a köz-

21 C-34/10. sz., Brüstle-ügyben hozott ítélet, 37. pont. A döntés részletes értékelését lásd SÁNDOR-VARJU: i. m., $120-121$.

22 Vesd össze: 1995. évi XXXIII. törvény a találmányok szabadalmi oltalmáról, 6 . § (3) bekezdés c) pont.

$23 \mathrm{Az}$ Európai Bíróság döntésének lehetséges következményeivel összefüggésben lásd: https://www. carpmaels.com/images/articles/1324399308_Exclusion\%20of\%20uses\%20of\%20human\%20mbryos. pdf (2015. 10. 02.). E helyütt említésre méltó az Emberi Jogok Európai Bíróságának Vo-ügyben hozott ítélete (Vo kontra Franciaország ügy, 2004. július 8-i ítélet [ügyszám: 53924/00]), mely a Brüstle-ügyhöz hasonlóan az embrióknak az őssejtkutatások során történő elpusztításával is foglalkozott, igaz, nem a szabadalmaztathatóság szempontjából. Habár a Bíróság utal arra, hogy az emberi méltóságból adódóan a magzatnak „védett erkölcsi státuszt” kellene biztosítani, tekintettel az embriók egyes részes államokban fennálló eltérő státuszára, a Brüstle-ügyhöz hasonlóan gyakorlatilag az államok mérlegelési jogkörébe utalja az élethez való jog kezdő időpontjának meghatározását („the issue of when the right to life begins comes within the margin of appreciation which the Court generally considers that States should enjoy in this sphere", 82. pont). Lásd részletesen SÁNDOR-VARJU: i. m., 113. 
egészségügy területét is. ${ }^{24}$ 2014. május 28-án a leköszönő Bizottság arra a következtetésre jutott, hogy a tagállamokkal és az Európai Parlamenttel is egyeztetett finanszírozási keret megfelelő, hiszen „az embrionális őssejtek egyedülállóak, és olyan életmentő kezelések kifejlesztésének a lehetőségét rejtik magukban, amelyek tekintetében már folynak klinikai vizsgálatok". ${ }^{25}$ Ezért a Bizottság nem módosítja az ilyen irányú kutatások uniós költségvetésböl történő finanszírozásának szabályait, hanem „továbbra is szigorú etikai szabályokat és korlátozásokat fog alkalmazni az uniós támogatást élvező kutatásokra, és ez egyben azt is jelenti, hogy nem fogja támogatni az embriók elpusztítását". ${ }^{26}$

A fentiek alapján az uniós jogalkotónak nincs egységes álláspontja az emberi embriók orvostudományi kutatása és felhasználása tekintetében: míg a szabadalmi irányelv teljes mértékben kizárja az emberi embriók felhasználásával kifejlesztett nem az embrió javát szolgáló gyógyászati vagy diagnosztikai célú ${ }^{7}$ - találmányok szabadalmaztathatóságát, addig a 2004/23/EK irányelv - a tagállamok releváns rendelkezéseitől függően - szabályozza azok terápiás célú kezelését. Mindezek tükrében megjegyzendő, hogy a vakcinák kifejlesztése során felhasznált emberi embriók tekintetében a haszonszerzési cél mellett olyan közérdeket szolgáló egészségvédelmi célok is felhozhatók, melyek legitimálhatják az embriókon végzett tudományos kísérleteket, illetve az embriók közvetlen felhasználását immunizáló oltások kifejlesztéséhez.

\subsection{Hazai szabályozás}

Az egészségvédelmi érdeket juttatja kifejezésre az egészségügyről szóló 1997. évi CLIV. törvény (Eütv.), mely lehetővé teszi az embriókon végzett tudományos kutatásokat. Azzal, hogy az Eütv. taxatív módon meghatározza a vonatkozó kutatások lehetséges céljait [159. § (1) bekezdés], nyilvánvaló, hogy a „tudományos kutatás” kizárólag az orvostudomány fejlődését szolgálhatja, kizárva ezáltal az embriók kereskedelmi jellegü hasznosítására irányuló kutatásokat a lehetséges kutatások és felhasználások köréből. Megemlítendő, hogy a büntető törvénykönyv (2012. évi C. törvény) 173. $\S(1)$ bekezdése szankciót is kapcsol mind az engedély nélküli vagy engedélytől eltérő, emberi embriókkal végzett orvostudományi kutatáshoz, mind pedig az embriókkal végzett bármilyen, egyéb kutatáshoz vagy kísérlethez. ${ }^{28}$

24 http://www.oneofus.eu/hu/initiative-explanation/ (2015. 10. 02.).

25 http://europa.eu/rapid/press-release_IP-14-608_en.htm (2015. 10. 02.).

26 http://europa.eu/rapid/press-release_IP-14-608_en.htm (2015. 10. 02.).

27 Az Európai Parlament és a Tanács 2004/23/EK irányelve az emberi szövetek és sejtek adományozására, gyűjtésére, vizsgálatára, feldolgozására, megőrzésére, tárolására és elosztására vonatkozó minőségi és biztonsági előírások megállapításáról (42) preambulumfordulata szerint „mivel ugyanakkor az emberi embrió ipari vagy kereskedelmi célra történő alkalmazását szintén ki kell zárni a szabadalmazhatóság köréből; továbbá mivel ez a kizárás semmi esetre sem érinti azokat a gyógyászati vagy diagnosztikai célú találmányokat, amelyeket az emberi embrión alkalmaznak, és annak javát szolgálják;" (kiemelés a szerzőtől).

28 173. § (1) Aki emberi embrión az embrió génállományának megváltoztatására irányuló kutatást végez, büntett miatt egy évtől öt évig terjedő szabadságvesztéssel büntetendő. (2) Aki a) emberi embriót a fogamzással 
Az emberi embriókon végzett tudományos kutatás szabályait az Eütv. 180. §-a szabályozza. A kutatás tárgyát kizárólag „a reprodukciós eljárások során létrejött embriók” képezhetik. A kutatás célja „kizárólag diagnosztikus, terápiás, megelőzési és rehabilitációs eljárások tökéletesítése, új eljárások kidolgozása, valamint a betegségek kóroktanának és patogenezisének jobb megértése, valamint az orvostechnikai eszközök hatékonyságával, teljesitőképességével kapcsolatos klinikai adat gyüjtése" lehet [Eütv. 159. § (1) bekezdés]. ${ }^{29} \mathrm{Az}$ embriókkal végzett kutatások szabályozási kerete szerint arra kizárólag a) „az egészségügyi államigazgatási szerv engedélye alapján; b) az engedélyben meghatározott dokumentációs rendnek és az egyidejüleg jóváhagyott kutatási tervnek megfelelően; és c) a kutatás célja szerinti szakmai feltételekkel rendelkezö egészségügyi szolgáltatónál vagy más kutatóhelyen végezhető kutatás".

A kutatásra vonatkozó szabályok betartásának ellenőrzésében a Humán Reprodukciós Bizottság szakhatóságként müködik közre.

Az Alaptörvénnyel, valamint a vonatkozó uniós szabályozással és joggyakorlattal összhangban a találmányok szabadalmi oltalmáról szóló 1995. évi XXXIII. törvény 6. § (3) bekezdésének c) pontja kifejezetten kizárja a szabadalmi oltalom alól az emberi embriók ipari vagy kereskedelmi célú hasznosítását.

A fentiek alapján elmondható, hogy a hazai szabályozás az oviedói egyezményben foglalt igen megengedő szabályoknak nagymértékben megfelel, mind a törvényi felhatalmazást, az embriók létrehozásának korlátait, illetve azok „megfelelő védelmét" tekintve.

\section{A tájékozott beleegyezés és az anya rendelkezési jogával kapcsolatos kérdések}

Az Alapjogi Charta 3. cikk (2) bekezdésének a) pontja alapján „[Az orvostudomány és a biológia területén különösen a következőket kell tiszteletben tartani:] az érintett személy szabad és tájékoztatáson alapuló beleegyezése a törvényben megállapított eljárásoknak megfelelöen".

Az Alapjogi Chartához készült Kommentár szerzői a Charta 3. cikk (2) bekezdésének a) pontjával kapcsolatban külön említést tesznek a tájékozott beleegyezés problémájáról. Eszerint, „mikor egy beavatkozás során az emberi test bármely részét eltávolítják, azt csak akkor tárolhatják és használhatják fel más célra, mint amelyért eltávolították, ha ezt a megfelelö tájékoztatási és beleegyezési eljárások alapján végzik. [...] Az elv valamennyi egészségügyi beavatkozás esetében érvényesül, azaz [...] a tudományos kutatási [célú beavatkozások esetében is]."

Kérdésként merül fel, hogy az anya testéből távozott elpusztult magzat „az emberi test részének" eltávolítását jelenti-e, illetve, hogy a tájékoztatás és az anya rendel-

kialakult tulajdonságoktól eltérő vagy további sajátosságokkal rendelkező egyed létrehozatalára használ fel, vagy b) emberi embrió sejtjeit szétválasztja, két évtől nyolc évig terjedő szabadságvesztéssel büntetendő.

29 Lásd ugyanakkor Eütv 181. § (2) bekezdés: „E törvény alkalmazása szempontjából nem minősül embriókutatásnak a diagnosztikai vagy gyógykezelési célból, valamint az embrió visszaültetésre vagy beültetésre való alkalmasságának megállapítása érdekében végzett vizsgálat." 
kezési joga kiterjed-e az elpusztult magzat további sorsával kapcsolatos kérdésekre is. Mivel a temetőkről és a temetkezésről szóló 1999. évi XLIII. törvény csupán az elpusztult magzatok eltemetésének szabályait rendezi - amennyiben erre egyáltalán sor kerül -, az elpusztult magzatok eltemetését megelőző intézkedések és az anya ezzel kapcsolatos tájékoztatási és rendelkezési joga is megvizsgálandó.

Az Unióban az emberi sejtek és szövetek átültetésével kapcsolatos eljárások tekintetében fogadtak el olyan európai normát (2004/23/EK tanácsi irányelv), mely a tájékozott beleegyezés elvére is tekintettel van. ${ }^{30} \mathrm{Az}$ irányelv kifejezetten hatálya alá vonja a magzati szöveteket és sejteket, valamint az embrionális őssejteket. Mellékletében tartalmazza az élő donor - esetünkben az anya - tájékoztatására vonatkozó minimális információkat, ezek között azonban nem szerepelnek a magzati szövetek és sejtek, őssejtek tárolásával, felhasználásával és esetleges megsemmisítésével kapcsolatos információk.

Az embrió feletti rendelkezés szabályait az Eütv. tartalmazza. A 175. § (1) bekezdése szerint „a reprodukciós eljárás során testen kívül létrejött és be nem ültetett embrióval kapcsolatos rendelkezés jogát az embriót létrehozó házastársak (élettársak) [...] közösen gyakorolják”. A (3) bekezdés alapján a rendelkezési jog az embrió „felhasználásának” három esetére terjed ki: (i) a saját célú későbbi felhasználásra (embrióletét); (ii) a más személyeknél történő reprodukciós eljárásban való felhasználásra (embrióadományozás); (iii) az orvostudományi kutatás céljára történő felajánlás.

Garanciális szabály, hogy a jogosultak kifejezett rendelkezése híján a saját felhasználási célú embrióletétet kell vélelmezni, illetve az embrió felajánlására kizárólag írásos nyilatkozatban kerülhet sor [175. § (3) bekezdés, 176. § (1) bekezdés].

A 176. § (4) bekezdés alapján „bármely szerv vagy személy a jogosulatlanul, illetőleg a jogszerüen, de [...] visszautasított felajánlás alapján birtokába jutott embriónak az arra jogosult más egészségügyi szolgáltatónál, illetve kutatóhelynél történő elhelyezéséről köteles intézkedni”, egyben az (5) bekezdés szerint az egészségügyi szolgáltató vagy kutatóhely az életképes embriót köteles átvenni. Károsodott embrió kizárólag kutatóhelynek adható át.

A 178. § (5) bekezdés szerint az adományozás céljából felajánlott emberi embrió legfeljebb öt évig tárolható, ám ez az időtartam egy alkalommal meghosszabbítható. Habár a fel nem használt embriók a tárolás leghosszabb idejének lejárta előtt nem semmisithetők meg, a határidő elteltét követően a birtokos egészségügyi szolgáltató az embriót megsemmisíti vagy tudományos kutatás céljára használja fel, illetve adja át az arra jogosult kutatóintézetnek.

30 Az emberi egészség magas szintű védelmének biztosítása érdekében (célkitűzés, 1. cikk) a közösségi jogalkotó megalkotta az Európai Parlament és a Tanács 2004/23/EK irányelvét az emberi szövetek és sejtek adományozására, gyűjtésére, vizsgálatára, feldolgozására, megőrzésére, tárolására és elosztására vonatkozó minőségi és biztonsági előírások megállapításáról. Az irányelv (7) preambulumbekezdésében a magzati szöveteket és sejteket, embrionális őssejteket kifejezetten a hatálya alá vonja. Az irányelv melléklete tartalmazza a sejtek és/vagy szövetek adományozása esetén nyújtandó információt. Eszerint az élő donorok esetében a donort legalább az alábbiakról kell tájékoztatni: a gyűjtés célja és jellege, annak következményei és kockázatai; az elemző vizsgálatok, amennyiben végeznek ilyet; a donorok adatainak nyilvántartása és védelme, az orvosi titoktartás; a gyógykezelés célja és potenciális haszna, valamint a donor védelmét szolgáló intézkedések. 
Visszásnak tekinthető, hogy a rendelkezésre jogosultak az embriót kifejezetten reprodukciós célból adományozták, abban a reményben, hogy embriójukkal egy másik család gyermekáldásához járulhatnak hozzá. Ehhez képest a fel nem használt embriójuk legkorábban öt, legkésőbb pedig tíz év múlva akár tudományos kutatásban is felhasználható. ${ }^{31}$

\section{A belső piac és a fogyasztók lelkiismereti szabadsága}

A fennálló uniós fogyasztóvédelmi szabályozás keretei között sérülhet a fogyasztók lelkiismereti szabadsága az emberi embriók vagy magzatok kereskedelmi jellegü felhasználásával készült termékekkel kapcsolatos megfelelő információk hiánya mi-

31 Habár a humán reprodukciós eljárásokból „fennmaradt” embriók esetében nem vetélésröl, elhalt terhességről van szó, az alapvető jogok biztosának megállapításai ilyen esetekben is megfontolandók: „noha az elhalt magzat formálisan nem minősül jogalanynak, így értelemszerüen az emberi méltósághoz való jognak sem lehet alanya, azonban ez a családjának a hozzá füződő viszonyán nem változtat. [...] [A]z az elhalt terhesség maradványainak egészségügyi hulladékként történő megsemmisítése teljes mértékben elfogadhatatlan és jogellenes gyakorlat." AJB 4291/2010.

A hazai szabályozás alapján az emberi embrió státusza és védelme nagymértékben függ fogantatásának módjától, genetikai állapotától és a rendelkezésre jogosultak döntésétől. Leszögezhető, hogy e szempontok alapján az Eütv. az egyes emberi embriók között különbséget tesz.

Az Eütv. 179. §-ának (3) bekezdése szerint „a testen kívül létrejött embriót a méhmagzat jogállása a beültetés napjától illeti meg", vagyis a méhmagzat számára biztosított feltételes életvédelem a humán reprodukciós eljárás során létrejött embrióknak időben később és csupán a beültetés feltételével jár. Navratyil szavaival „az egészségügyi törvény tehát visszavesz az ember eddig elért pozíciójából, az anyatesten kívüli embriónak feltételes jogképessége nincs, ami az anyatesten belülinek van" (NAVRATYIL: i. m., 149).

Az Eütv. 182. §-ának (4) bekezdése kifejezetten megköveteli a jogosultak írásbeli beleegyező nyilatkozatát, hogy a reprodukciós eljárás során az utód nemének megállapítása, betegségeinek megelőzése, felismerése és kezelése érdekében az embrión beavatkozásokat végezzenek el. Olybá tűnik, hogy a jogosultak rendelkezési joga, valamint az embrió beavatkozásoktól való védettsége az embrió minőségétől (károsodott vagy sem), illetve a jogosultaknak az embrió felhasználásáról szóló döntése függvényében alakul. Ami az első szempontot illeti, meg kell említeni, hogy a károsodott embriók kizárólag tudományos kutatás tárgyai lehetnek. Hasonló eredményre jut a Humán Reprodukciós Bizottság a Preimplantatiós Genetikai Diagnosztikával kapcsolatos állásfoglalásában: „Az eljárás alkalmazása számos etikai kérdést is felvet. Ezek elsősorban a betegséget hordozó, és így beültetésre nem kerülő előébrények megsemmisítése miatt merülnek fel. Így a PGD alkalmazása feltételezi, hogy etikai szempontból különbséget teszünk a betegséget hordozó és méhen belül fejlődő, valamint az IVF-kezelés útján létrehozott, a betegségben szintén érintett és ezért beültetésre nem kerülő előébrények megsemmisítése között." (Elfogadva a HRB 2008. november 17-i ülésén); lásd a dokumentum 6 . oldalát.

Az oviedói egyezmény 11. cikke kifejezetten tiltja „az egyén örökletes genetikai állománya alapján történő hátrányos [megkülönböztetés minden formáját]” - jelen esetben akár az embriók „minősége” szerinti szelekciót. Mivel azonban a magyar jog ezt lehetővé teszi, arra következtethetünk, hogy az emberi embriót nem vonta az egyezmény „egyén” fogalma alá. Ami a második szempontot, azaz az embrió felhasználásáról szóló döntést illeti, elmondható, hogy amennyiben jogosultak kifejezetten vagy hallgatólagosan az embrióletét felől rendelkeznek, a határidő lejártával embriójuk megsemmisítésre kerül. Amennyiben azonban embriót adományoznak, a határidő lejártával az embrió akár tudományos kutatásra is átadható. Mindezek alapján megállapíthatjuk, hogy a nem károsodott, saját felhasználásra szánt embriók védettségi szintje magasabb, mint az egyéb embrióké.

A károsodott embriók vitatott státuszával kapcsolatban lásd DE MıGUEL BERIAIN, Ińigo: What is a Human Embryo? A New Piece in the Bioethics Puzzle. Croatian Medical Journal, 2014/12, 671. 
att, hiszen ezek a termékek a belső piacra is bekerülhetnek. ${ }^{32} \mathrm{Az}$ embriókon, illetve magzatokon végzett kísérletek révén kifejlesztett termékek jellemző kategóriái az élelmiszerek, kozmetikumok és vakcinák. E termékek az ilyen kutatásokat vallási, lelkiismereti alapon elutasító fogyasztó szempontjából azért is különösen érzékenyek, hiszen ezeket a fogyasztó szó szerint elfogyasztja: azok testébe beépülnek, illetve szervezete hasznosítja ezeket. Ha csak arra gondolunk, hogy egy elkötelezett állatvédő számára milyen lelkiismereti aggályt jelenthet egy állatkísérletekkel előállított termék fogyasztása, egy vegetáriánus számára az állati eredetű termékek fogyasztása, könnyű belátni, hogy bizonyos vallási és világnézeti meggyőződésű személyek számára elfogadhatatlan az emberi embriók, magzatok felhasználásával készült termékek fogyasztása. ${ }^{33}$

Mivel az Unióban (Alapjogi Charta 10. cikk) és hazánkban (Alaptörvény VII. cikk) biztosított a lelkiismereti és vallásszabadság, garanciális jelentősége van annak, hogy a fogyasztó ezen alapjogának gyakorlásához a jelenlegi címkézési előírásokon túlterjeszkedő, a termék tartalmával és létrehozása körülményeivel kapcsolatos információkhoz is hozzáférjen, illetve túlzott terhek vállalása nélkül is dönthessen arról, hogy egy adott termék fogyasztása összeegyeztethető-e vallási vagy világnézeti elkötelezettségével.

Az Unió fogyasztóvédelmi szabályozási céljait a 2007-2013-as időszakra az Európai Parlament és a Tanács 1926/2006/EK határozata tartalmazta. ${ }^{34}$ A határozat 2. cikk (1) bekezdése alapján a program célja egyebek között az, hogy hozzájáruljon a „fogyasztók [...] törvényes érdekeinek védelméhez, valamint információhoz való joguk erösitéséhez”. A (2) bekezdés szerint e cél elérése egyebek között a „pontosabb adatok” biztosítása és a „tájékoztatásra” vonatkozó szabályok eredményesebb alkalmazása révén történik meg. ${ }^{35} \mathrm{~A}$ fogyasztó védelmét a belső piacon elsősorban az

32 A magzatok kereskedelmi célú felhasználásával készült termékek belső piacra kerülésének kérdése tekintetében például elég csak az Amerikai Egyesült Államokban érvényes jogszabályokra utalni. Az amerikai szabályozás lényege, hogy bár valamennyi összetevőt fel kell tüntetni az élelmiszerek, gyógyszerek és kozmetikumok címkéjén, egy előzetes, bizalmas eljárás keretében a gyártó kérheti, hogy az általa alkalmazott összetevőt „üzleti titoknak” minősítsék, mely alapján mentesül az összetevő címkén való szerepeltetésétől, és csupán az „egyéb összetevő” kerül fel a címkére. Mivel az „egyéb összetevő” bármilyen, a cég által fejlesztett titkos összetevő lehet (például PSP ${ }^{\circledR}$ ), a fogyasztó nem értesülhet róla, hogy mely esetben takarja ez a fordulat az embrionális eredetü összetevőt. A PSP ${ }^{\circledR}$-t kifejlesztő svájci Neocutis valamennyi kereskedelmi tevékenységét amerikai leányvállalatán keresztül bonyolítja. http://www.neocutis.com/corporate (2015. 10. 02.).

33 Lásd: AJB-3119/2014 sz. ügy.

34 Az Európai Parlament és a Tanács 1926/2006/EK határozata (2006. december 18.) a fogyasztóvédelmi politika területén közösségi cselekvési program (2007-2013) létrehozásáról. HL L 404, 30/12/2006, 39-45.

35 2. cikk, Célkitűzések:

(1) A program célja, hogy kiegészítse, támogassa és nyomon kövesse a tagállamok szakpolitikáit, és hozzájáruljon a fogyasztók egészségének, biztonságának és gazdasági és törvényes érdekeinek védelméhez, valamint információhoz való joguk erősítéséhez, oktatásukhoz, és ahhoz, hogy megszervezzék saját érdekeik védelmét.

(2) Az (1) bekezdésben meghatározott cél elérése a következő célkitüzések megvalósitása révén történik: a) a fogyasztóvédelem magasabb szintjének biztositása, föleg pontosabb adatok, jobb konzultáció és a fogyasztói érdekek jobb képviselete révén;

b) a fogyasztóvédelmi szabályok eredményesebb alkalmazásának biztositása, különösen a jogalkalmazói együttmüködés, a tájékoztatás, az oktatás és a jogérvényesités révén. 
uniós fogyasztóvédelmi szabályozás szolgálja, melynek célja, hogy a fogyasztó széles körü tájékoztatást kapjon az elérhető termékekről. A fogyasztóvédelmi célokat termékcímkézési szabályok ültetik át; az Unió pedig külön speciális rendelkezéseket fogadott el az egyes élelmiszerek, valamint a kozmetikumok címkézésére nézve.

Ami e termékkategóriák címkézésére vonatkozó uniós szabályokat illeti, ezekre a fragmentáció jellemző: közös szabályozást ugyan mind az élelmiszerek, ${ }^{36}$ mind pedig a kozmetikumok területén sikerült megalkotni, ugyanakkor elmondható, hogy míg a kozmetikumok címkézési szempontból egységes szabályozás alá esnek, az élelmiszerek egyes kategóriái különleges címkézési szabályoknak vannak alávetve.

\section{1. Élelmiszerek}

Az élelmiszergyártás köréből a magzati sejtvonalak felhasználása miatt vitatott termékként a Senomyx HEK 293-mal tesztelt ízfokozói szolgálhatnak például. A Senomyx szolgáltatásait egyes hírek szerint olyan cégek vették igénybe, mint a Kraft Foods ${ }^{37}$ és a Nestlé, mely cégek termékei szabadon forgalmazhatók az Unióban és hazánkban.

Azélelmiszerekre vonatkozó címkézési szabályok nem tesznek említést az embrionális vagy magzati sejtek és szövetek bármilyen fajtájú (kísérleti anyag, összetevő) és célú felhasználásáról. Az átfogó 2000/13/EK irányelv (6) preambulumbekezdése szerint „[a]z élelmiszerek címkézésére vonatkozó szabályoknak elsődlegesen a fogyasztó tájékoztatását és védelmét kell szolgálniuk", míg a (8) preambulum-bekezdés szerint: „A legmegfelelőbb a részletes címkézés lenne, amely megadja a termék pontos jellegét és jellemzőit, és amely lehetővé teszi a fogyasztó számára a tények teljes ismeretében történő választást." Mindezek alapján az irányelv (9) preambulumbekezdése kimondja, hogy „ezért egy listát kell összeállítani az olyan információkról, amelyeket elvben az összes élelmiszer címkézésének tartalmaznia kellene”. Ezek elfogadását azonban az irányelv egy későbbi időpontra halasztja. ${ }^{38}$

Az élelmiszerek címkézéséről szóló irányelv 3. cikke alapján - egyebek között - a következőket kell feltüntetni az élelmiszerek címkéjén: összetevők listája és bizonyos összetevők vagy összetevő-kategóriák mennyisége. Az emberi embriók vagy magzatok felhasználásával fejlesztett összetevőket esetlegesen tartalmazó élelmiszerek esetében érdekes, hogy a 3. cikk (4) bekezdésének a) pontja szerint „összetevőnek” minősül „minden anyag, beleértve az adalékanyagokat is, amelyet élelmiszer előállításánál vagy elkészítésénél használnak fel, és a késztermékben

36 Az Európai Parlament és a Tanács 2000/13/EK irányelve (2000. március 20.) az élelmiszerek címkézésére, kiszerelésére és reklámozására vonatkozó tagállami jogszabályok közelítéséröl; HL L 109, 06/05/2000, 29-42.

37 http://www.lifenews.com/2011/03/31/companies-stop-using-abortion-cells-to-test-artificial-flavors/ (2015. 10. 02.); http://www.wsj.com/articles/SB976488959948883459 (2015. 10. 02.); http://www.foodnavigator-usa. com/R-D/Senomyx-Kraft-to-work-on-dessert-flavour-modifier (2015. 10. 02.).

38 „(10) Ezen irányelv horizontális jellegéből fakadóan a kezdeti szakaszban nem lehet kötelezővé tenni az összes olyan jelzést, amelynek az összes, élelmiszerre vonatkozó listára kell kerülnie. Egy későbbi stádiumban közösségi rendelkezéseket kell elfogadni, amelyek célja a meglévő szabályok kiegészítése." 
még jelen van, akár módosult formában is". Az irányelv (11) preambulumbekezdése szerint „különös közösségi szabályok hiányában a tagállamoknak fenn kell tartaniuk a jogot, hogy bizonyos nemzeti rendelkezéseket állapitsanak meg, amelyek hozzáadhatók ezen irányelv általános rendelkezéseihez, jóllehet e rendelkezéseket közösségi eljárásnak kell alávetni”, továbbá a 3. cikk (7) bekezdés szerint: „Közösségi rendelkezések, vagy ezek hiányában a nemzeti rendelkezések állapithatják meg, hogy az árumegnevezést kísérje-e a speciális összetevő vagy összetevők említése."

Fontos rámutatni, hogy az irányelv alapján például a fent említett Senomyx által HEK 293 megjelölésű magzati sejtvonalak felhasználásával kifejlesztett ízfokozók nem minősülnek összetevőnek, arra a címkézésnél nem kell utalni.

\subsection{Kozmetikumok}

A svájci Neocutis égési sérültek bőrregenerációjára kifejlesztett $P S P^{\circledR}$ terméke illusztrálhatja a magzati sejtvonalak felhasználásával kifejlesztett kozmetikumok körét. APSP ${ }^{\circledR}$ egy 14 hetes abortum bőrsejtjeinek felhasználásával kifejlesztett fehérje, amely gyorsítja a bör hegmentes gyógyulását, és immár nem csupán égési sebekre, hanem öregedésgátló krémként is forgalmazzák. ${ }^{39}$

A kozmetikumokra vonatkozóan 2013. január 1-i hatállyal az Európai Parlament és a Tanács megalkotta az 1223/2009/EK rendeletet ${ }^{40}$, mely egyben hatályon kívül helyezi az azonos szabályozási tárgykörben született 76/768/EGK irányelvet. Az új rendelet II. Mellékletében tartalmazza a „Kozmetikai termékekben tiltott anyagok listáját”, melynek 416. tétele a „sejtek, szövetek és emberi eredetü termékeket” tartalmazza - tehát a hatályos rendelet kizárja az embrionális vagy magzati eredetủ anyagoknak a kozmetikai termékekben való szerepeltetését [14. cikk (1) bekezdés]. Ugyanakkor a melléklet lakonikus megfogalmazásából nem derül ki, hogy a „tiltott anyagok" pontosan milyen felhasználásra terjednek ki: például idetartoznak-e azok az anyagok, melyek közegként vagy más formában segítik elő a termék létrehozását, kifejlesztését? A releváns rendelkezések összessége arra az értelmezésre vezet, hogy a kozmetikai termék összetevőjeként nem jelenhet meg a sejt, szövet, emberi eredetű termék, minden egyéb felhasználásuk azonban lehetséges. Erre utal a 17. cikk is, mely a tiltott anyagoknak a termékekben nyomokban való fellelhetöségét szabályozza: a tiltott anyagnak a nem szándékos termékbe kerülése a gyártás, csomagolás, tárolás stb. során jogszerủ lehet, amennyiben a termék a 3. cikk értelmében megfelel a biztonsági elöírásoknak.

Fontos szempont lehet azonban, hogy az új kozmetikai rendelet a korábbival ellentétben már tartalmazza a „sejtek, szövetek és emberi eredetű termékekre” vonatkozó tiltást, ellentétben a korábbi jogszabállyal. Ennek oka lehet, hogy a jogalkotó

39 MARIETTA, Cynthia S.: Ingredient in Anti-Aging Cosmetic Re-Ignites Abortion Debate and Raises Questions About Cosmetic Labeling. http://www.law.uh.edu/Healthlaw/perspectives/2010/(CM)\%20Cosmetic.pdf (2015. 10. 02.), 1. és 5.

40 Az Európai Parlament és a Tanács 1223/2009/EK rendelete (2009. november 30.) a kozmetikai termékekről; HL L 342, 22/12/2009, 59-209. 
esetleg szembesült már sejtek, szövetek, emberi eredetü termékek felhasználásával készült kozmetikumokkal, vagy felismerte az ebben rejlő lehetséges veszélyeket; esetleg morális alapú döntés eredményeként jelent meg a tiltás. Mindezek alapján a kor technológiai lehetőségeire is figyelemmel, az uniós jogalkotó elmozdult az emberi eredetủ anyagoktól mentes kozmetikumok felé, ebből pedig a lehetséges jövőbeli jogfejlődést illetően is következtetéseket vonhatunk le. ${ }^{41}$

\section{6. Összefoglalás}

Az emberi embriók, magzatok kereskedelmi felhasználása számos morális és jogi aggályt vet fel. Végigtekintve az uniós és a hazai jogi szabályozást, úgy tűnik, az irányadó jogi keretek nincsenek felkészülve a biológiai mérnökösködés fejlődésének következményeire. Miközben például még az emberi embriók és magzatok státusza is vitatott, ${ }^{42}$ addig a felhasználásuk és az így kifejlesztett termékek fogyasztása során számtalan olyan alapvető jog sérülhet, mint amilyen a tájékozott beleegyezés vagy a vallási és lelkiismereti szabadság. Mind az uniós, mind pedig a hazai jogalkotónak fel kell készülnie azokra a kihívásokra, melyeket a XXI. századi sejtkutatás és az egyre összetettebb termékgyártás jelent.

\section{Abstract}

In 1986 the Council of Europe adopted a recommendation on the use of human embryos and foetuses for diagnostic, therapeutic, scientific, industrial and commercial purposes [Parliamentary Assembly Recommendation 1046 (1986)]. At the time, biotechnology was less advanced than today, however, its main challenges were already apparent. In its Recommendation, the Council of Europe called upon the Member States to restrict the industrial use of human embryos to therapeutic purposes benefiting the health of the respective embryos, while the tissues of dead foetuses may only be used for strictly medical, scientific purposes. The commercial, profit-oriented use of embryos or fetal tissue is prohibited, with special regard to human dignity. Today, we are faced with the growing risk of encountering products manufactured on the basis of experiments conducted with, or base material including human embryonic cell lines. Such commercial and industrial uses of human embryos and foetuses give rise to concerns related to the religious freedom and the freedom of conscience, fundamental rights protected by both national constitutions and the Charter of Fundamental Rights.

\footnotetext{
41 Kérdéses, hogy a 2013 előtt hatályos kozmetikai szabályok hatálya alatt készültek-e emberi (embrionális) sejteket, szöveteket tartalmazó kozmetikumok, hiszen amennyiben igen, ezek lejáratukig, 2013-on túl is forgalomban maradhatnak a belső piacon, hiszen visszavonásukat az új rendelet nem szabályozza.

42 SÁNDOR-VARJU: i. m., 99.
} 